\title{
Expanding the geographical distribution of the Egyptian Mongoose, Herpestes ichneumon (Linnaeus, 1758), in South Africa
}

\author{
Lourens H. Swanepoel ${ }^{1}$, Daan Loock ${ }^{2,3}$, Wayne S. Matthews ${ }^{4,5}$, Kevin W. Emslie ${ }^{1}$ \\ 1 Department of Zoology, School of Mathematical and Natural Sciences, University of Venda, Private Bag X5050, Thohoyandou, 0950, South \\ Africa. 2 Faculty of Natural and Agricultural Sciences, University of the Free State, 205 Nelson Mandela Drive, Park West, Bloemfontein, 930, \\ South Africa. 3 Secunda Synfuels Operations, Private Bag X1000, Secunda, 2302, South Africa. 4 Department of Environmental Sciences, \\ College of Agriculture and Environmental Sciences, University of South Africa, P.O. Box 392, Pretoria, 0003, South Africa. 5 Wildlife Resource \\ Association, PO Box 1288, Umhlali, 4390, South Africa. \\ Corresponding author: Lourens Swanepoel, lourens.swanepoel.univen@gmail.com
}

\begin{abstract}
The current geographical distribution of the Egyptian Mongoose or Large Grey Mongoose, Herpestes ichneumon (Linnaeus, 1758), in South Africa is limited to the south-eastern coastal and eastern sections of the country. One recent sighting in the central part of the country suggested a wider geographical distribution. In this study, we report on confirmed sightings of the Egyptian Mongoose on consecutive years in the central part (at Sasol's Synfuels Plant in Secunda) of the country. Our sightings thus expand the distribution of the Egyptian Mongoose in South Africa to include some sections of the central to eastern part of the country.
\end{abstract}

\section{Key words}

Mpumalanga; range expansion; Grassland biome.

Academic editor: Guilherme S. T. Garbino | Received 24 May 2018 | Accepted 9 July 2018 | Published 20 July 2018

Citation: Swanepoel LH, Loock D, Matthews WS, Emslie KW (2018) Expanding the geographical distribution of the Egyptian Mongoose, Herpestes ichneumon (Linnaeus, 1758), in South Africa. Check List 14 (4): 595-599. https://doi.org/10.15560/14.4.599

\section{Introduction}

The Egyptian Mongoose, or Large Grey Mongoose, Herpestes ichneumon (Linnaeus, 1758), occupies a vast range in Africa, with the exception of deserts (Fig. 1A). The known distribution of the Egyptian Mongoose in South Africa is restricted to the south-eastern to eastern coastline and eastern sections of the country (Fig. 1A, C) (Palomares 2013). The Egyptian Mongoose is a terrestrial, predominantly solitary species, occurring in habitats with well-developed understory in coastal, lacustrine, and riparian environments (Palomares 2013). Although it is an opportunistic omnivore, it preys on small mammals (Stuart 1983), including vlei rats, Otomys spp. and mul- timammate mice, Mastomys spp. (Smithers and Wilson 1979, Angelici 2000). Throughout its African range, the Egyptian Mongoose is classified as Least Concern by the International Union for Conservation of Nature (IUCN) (Do Linh San et al. 2016a) and the South African Red List assessment (Do Linh San et al. 2016b).

\section{Methods}

The study was done under permit issued by the Mpumalanga Tourism and Parks Agency (permit no. 5467). Photographs for this study were collected during a study on the population ecology of Serval, Leptailurus serval (Schreber, 1776), at the Sasol Synfuels Plant in Secunda 

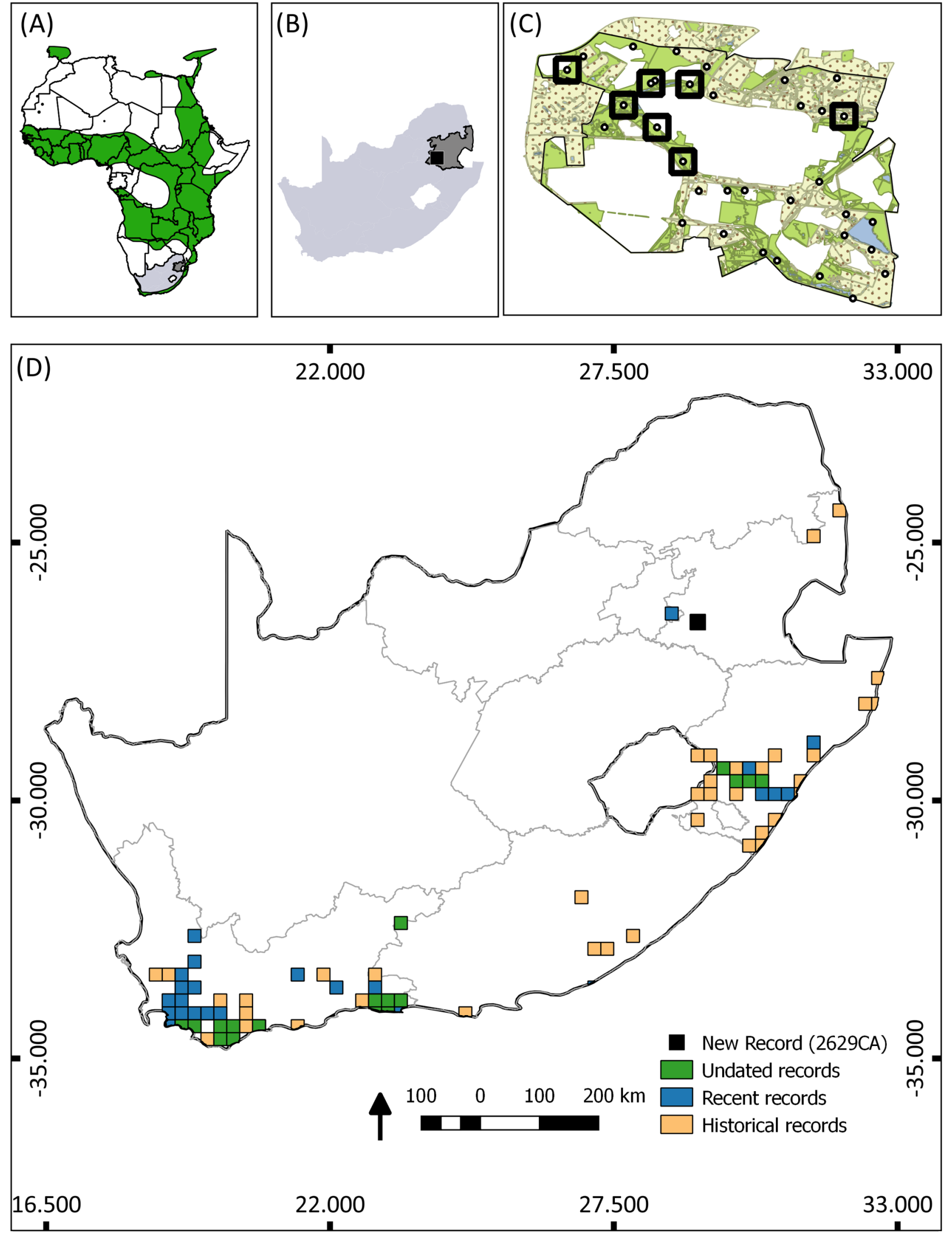

Figure 1. Range of Egyptian Mongoose, Herpestes ichneumon (Linnaeus, 1758). A. African range (grey represents South Africa). B. Study site (black square) in relation to Mpumalanga Province (dark grey), South Africa. C. Camera trapping layout and study area; white circles represent camera trap locations and black squares indicate sites were Egyptian Mongoose were photographed. D. Historic, recent, and undated Egyptian Mongoose observations in South Africa, the black square represents the new confirmed observations from this study. 
(central coordinates $26^{\circ} 31^{\prime} 46^{\prime \prime} \mathrm{S}, 2^{\circ} 10^{\prime} 32^{\prime \prime} \mathrm{E}, 3000$ ha; Fig. 1B, C) between August 2014 and November 2016. The Sasol Synfuels Plant consists of a primary area (the petrochemical plant itself) and a secondary area (surrounding natural and disturbed vegetation). Camera trapping was done in the secondary area where the vegetation is classified at Soweto Highveld Grassland (Mucina et al. 2006), which falls in the Grassveld Biome (Mucina et al. 2006). The secondary area is dominated by natural grasslands interspersed with both natural and man-made wetlands. Approximately $38 \%$ of the secondary area is classified as untransformed while the remaining $62 \%$ is classified as disturbed vegetation.

During survey periods we deployed an array of 34 Reconyx $^{\mathrm{TM}}$ Hyperfire ${ }^{\mathrm{TM}}$ HC600 camera traps. Survey duration varied between years (2014: August to December; 2015: January to September; 2016: October to November). Traps were placed at least $1.2 \mathrm{~km}$ apart, raised about 50 $\mathrm{cm}$ off the ground on wooden stakes, and generally placed on vehicle roads or animal paths. Trap deployment and placement were done to maximize detection of Serval, and therefore the majority of traps were deployed in areas close to wetlands.

\section{Results}

During10,160 camera trapping days (2014-2016) we detected the Egyptian Mongoose at 8 camera trap sites (Table 1; Fig. 1C). Egyptian Mongooses were detected at 1 camera station in 2014, 2 camera stations in 2015, and 4 camera stations in 2016 (Table 1). The majority of detections (7 out of 8 ) were made in wetland or wetland-related habitat types (Table 1; Fig. 1C). Besides the Egyptian Mongoose, another 10 species of carnivores were recorded.

Identification. Egyptian Mongoose were identified by their characteristic long guard hairs, longer hair at the base of tail compared to the tip (Fig. 2A), and a black tailtip (Fig. 2B) (Palomares 2013). Interestingly, on some of the camera trap photographs, the black tail-tip was not apparent (4 out of 8 photographs: Fig. 2A), which seems related to the camera trap angle.

\section{Discussion}

The Egyptian Mongoose appears to prefer riparian, lacustrine, and coastal habitats (Palomares and Delibes 1993, Angelici 2000). These habitat associations are concordant with our results where the majority of photo-detections occurred in wetland vegetation. Egyptian Mongooses have also been observed in grazed vegetation, as well as cultivated and irrigation fields, suggesting that they are not deterred by human presence (Palomares 2013). Our results concur with this as we detected Egyptian Mongooses in areas frequented by humans.

Our detections ranged from 265 to $288 \mathrm{~km}$ west (Fig. 1D) of the previously known westernmost occur- rence record of the Egyptian Mongoose in South Africa. However, our detections were only $60 \mathrm{~km}$ to the east of a 2016 sighting in the $2628 \mathrm{BC}$ quarter degree grid. The 2016 sighting, combined with our detections, suggest that the geographical distribution of the species is larger than currently estimated. While these "extralimital" detections might be interpreted as being indicative of range expansion, it may be merely a result of this species being underdetected due to its cryptic habits (Do Linh San et al. 2016b). Furthermore, Egyptian Mongoose populations might be constrained by the presence of larger predators like Black-backed Jackals, Canis mesomelas Schreber, 1775, and Caracals, Caracal caracal (Schreber, 1776) (Do Linh San et al. 2016b).

Our detections of Egyptian Mongooses, over an extended period, outside their known range is attributable to either range expansion or underdetection of the species. We, therefore, suggest that future studies are needed to validate our observations and to determine whether this species is present in other wetland and riparian areas where it has not previously been detected. Investigations into the use of Egyptian Mongooses as bioindicators for monitoring wetland habitats should be pursued.

\section{Acknowledgements}

Funding for the project was supplied by Sasol Synfuels; LHS and KWE were supported by funding from the National Research Foundation in South Africa (UID 107099) and LHS was further supported by the University of Venda (SMNS/17/Zoo/01).

\section{Authors' Contributions}

KWE and DL collected and catalogued the data, WM assisted in project design and management, LHS wrote the first draft, validated the data, and subsequent editorial work.

\section{References}

Angelici FM (2000) Food habits and resource partitioning of carnivores (Herpestidae, Viverridae) in the rainforests of southeastern Nigeria: preliminary results. Revue d'Ecologie (Terre et Vie) 55: 67-76.

Do Linh San E, Maddock AH, Gaubert P, Palomares F (2016a) Herpestes ichneumon. The IUCN Red List of Threatened Species 2016. https://doi.org/10.2305/iucn.uk.2016-1.rlts.t41613a45207211.en. Accessed on: 2018-5-19.

Do Linh San E, Emslie K, Maddock AH, Perrin MR, Stuart C, Stuart M, Palomares F (2016b) A conservation assessment of Herpestes ichneumon. In: Child MF, Roxburgh L, Do Linh San E, Raimondo D, Davies-Mostert HT (Eds). The Red List of Mammals of South Africa, Swaziland and Lesotho. South African National Biodiversity Institute and Endangered Wildlife Trust, South Africa, 1-7.

Mucina L, Hoare DB, Lötter MC, Du Preez PJ, Rutherford MC, ScottShaw CR, Bredenkamp GJ, Powrie LW, Scott L, Camp KGT, Cilliers SS, Bezuidenhout H, Moster TH, Siebert SJ, Winter PJD, Burrows JE, Dobson L, Ward RA, Stalmans M, Oliver EGH, Siebert F, Schmidt E, Kobisi K, Kose L (2006) Grassland biome. In: Mucina L, Rutherford MC (Eds). The Vegetation of South Africa, Lesotho and Swaziland. South African National Biodiversity Institute, Pretoria, 350-431. 
Table 1. Photo-detections of the Egyptian Mongoose, Herpestes ichneumon (Linnaeus, 1758) at the Sasol Synfuels Plant in Secunda, Mpumalanga, South Africa during 2014-2016.

\begin{tabular}{lllll}
\hline Date & Time & Longitude & Latitude & Vegetation type \\
\hline 8 October 2014 & $09: 14: 48$ AM & 29.13217 & -26.53426 & Wetland and grassland \\
5 November 2014 & $09: 13: 53$ AM & 29.13217 & -26.53426 & Wetland and grassland \\
19 February 2015 & $10: 46: 33$ AM & 29.13410 & -26.54812 & Wetland \\
12 March 2015 & $01: 15: 23$ PM & 29.12358 & -26.54114 & Wetland and grassland \\
27 October 2016 & $08: 38: 35$ PM & 29.19299 & -26.54466 & Wetland and grassland \\
29 October 2016 & $07: 54: 48$ AM & 29.14438 & -26.53457 & Wetland \\
5 November 2016 & $06: 34: 11$ AM & 29.10582 & -26.53008 & Grassland \\
5 November 2016 & $12: 41: 58$ PM & 29.14225 & -26.55894 & Wetland
\end{tabular}

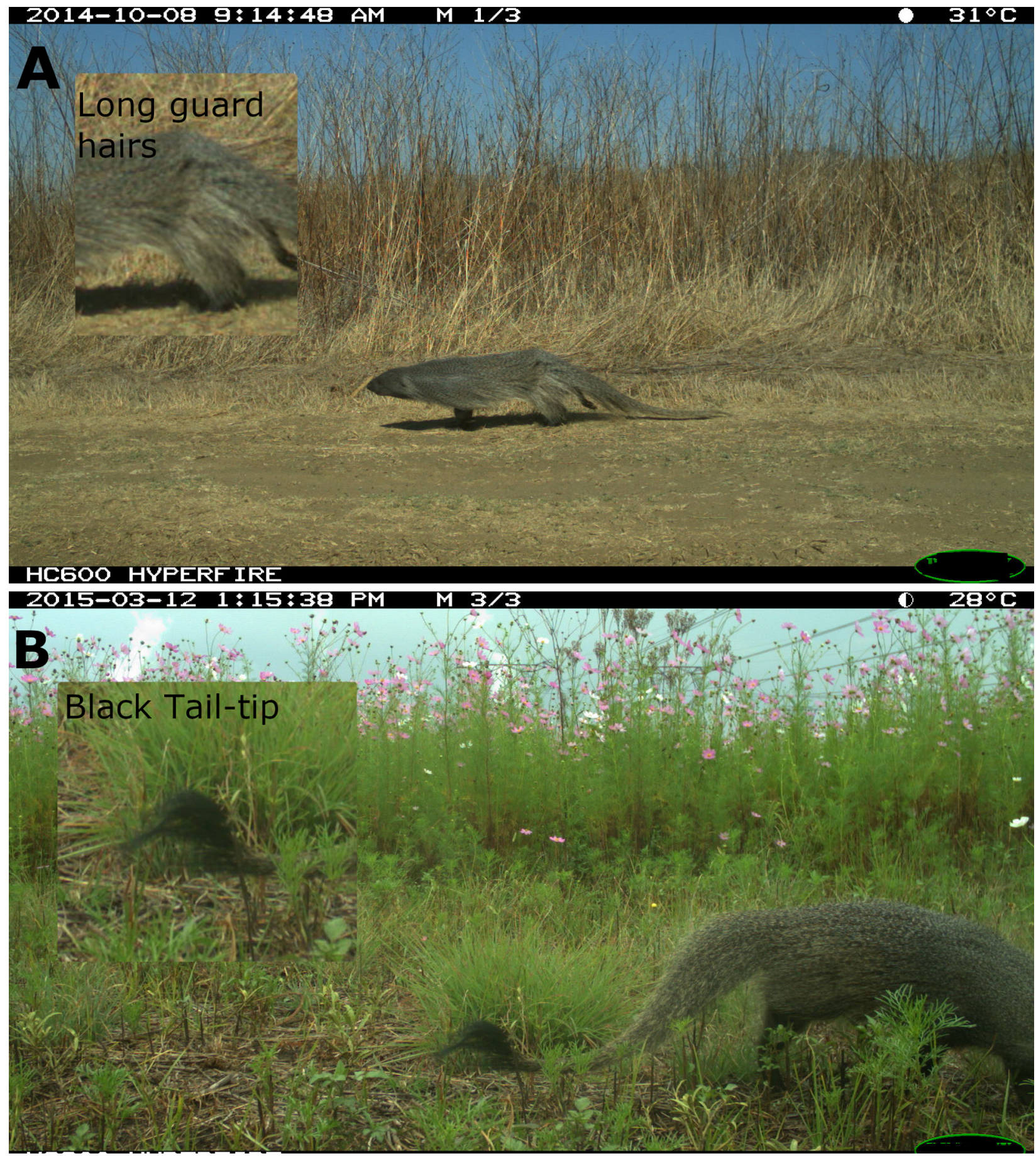

Figure 2. Camera trap photographs of Egyptian Mongoose, Herpestes ichneumon (Linnaeus, 1758). A. Detail of the characteristic long guard hair, long hair at base of tail, but here black tail-tip is not apparent. B. Detail of the characteristic black tail-tip. 
Palomares F (2013) Herpestes ichneumon Egyptian Mongoose (Ichneumon). In: Kingdon J, Hoffmann M (Eds) The Mammals of Africa. V. Carnivores, Pangolins, Equids and Rhinoceroses. Bloomsbury, London, 306-310.

Palomares F, Delibes M (1993) Key habitats for Egyptian mongooses in Doñana National Park, south-western Spain. Journal of Applied Ecology 30: 752-758.
Smithers RHN, Wilson VJ (1979) Check list and atlas of the mammals of Zimbabwe Rhodesia. Museum Memoirs No 9. National Museums and Monuments of Rhodesia, Salisbury, Zimbabwe, 147 pp. Stuart CT (1983) Food of the large grey mongoose Herpestes ichneumon in the south-west Cape Province. South Africa Journal of Zoology 18: 401-403. https://doi.org/10.1080/02541858.1983.11 447845 